\title{
EFFECT OF MONENSIN IN AMELIORATING SUBACUTE LACTIC ACIDOSIS IN BUFFALO CALVES
}

\author{
A. K. AHUJA, S. S. RANDHAWA and S. S. RATHOR
}

Department of Veterinary Medicine, Punjab Agricultural University, Ludhiana 141004, India

Received fune 14, 1988

\begin{abstract}
Ahuja A. K., S. S. Randhawa, S. S. Rathor: Effect of Monensin in Ameliorating Subacute Lactic Acidosis in Buffalo Calves. Acta vet. Brno, 59, 1990: 171-178.

The efficacy of monensin feeding on rumen metabolism, acid base status and gas tension of blood in molasses induced subacute lactic acidosis in buffalo-calves was evaluated. Subacute lactic acidosis was induced by oral administration of molasses at a dose $10 \mathrm{~g} / \mathrm{kg}$ body mass as a single dose. Monensin was found to be effective in improving rumen liquor $\mathrm{pH}$ and significantly decreasing the lactic acid content of rumen liquor. The total volatile fatty acid (TVFA) concentration and their individual proportion was not affected following administration of first dose of monensin at $12 \mathrm{~h}$ after experimental induction. However, administration of second dose at $24 \mathrm{~h}$ resulted in marked increase in the concentration of TVFA associated with decrease in the ruminal acetate and butyrate production and proportionate increase in the ruminal propionate concentration. The blood lactic acid content also showed a significant decline in the monensin treated group indicating its efficacy also in combatting developing systemic acidosis as reflected by improvement in the actual bicarbonate, standard bicarbonate, acid base excess and bicarbonate to carbonic acid ratio following acid-base analysis of the venous blood.
\end{abstract}

Rumen acidosis, Ionophore antibiotic, acid base status, tumen metabolism

It has been demonstrated that growth of major lactate producing bacteria Streptococcus bovis and Lactobacillus spp. is inhibited by the antibiotic monensis (Dennis et al. 1981a). This antibiotic also helps in lowering the lactic acid content in the in vitro rumen fermentations ( $\mathrm{Na-}$ garaja et al. 1981). Selective inhibition of major lactate producing bacteria by monensis in vitro suggests its potential use in controlling lactic acidosis in ruminants. The objective of this study was, therefore, to test the efficacy of monensin feeding on rumen metabolism and acid-base status of blood under molasses induced subacute lactic acidosis in buffalo calves.

\section{Materials and Methods}

The experiment was carried out on four Murrah buffalo calves of about one year age. Three of the calves were placed on monensin treatment and the fourth was kept as control. After an overnight fasting subacute lactic acidosis was induced in all the calves by oral feeding of molasses at a dose $10 \mathrm{~g} / \mathrm{kg}$ body mass as a single dose.

After the induction of acidosis, the first dose of monensin was given orally at a dose $3 \mathrm{mg} / \mathrm{kg}$ body mass after $12 \mathrm{~h}$ of induction and the same dose repeated $24 \mathrm{~h}$ after induction.

Ruminal and blood samples were collected every $6 \mathrm{~h}$ from 0 to 24 , then every $12 \mathrm{~h}$ from 24 to $48 \mathrm{~h}$. Rumen liquor samples treated with $0.5 \mathrm{ml}$ of saturated mercuric chloride were collected via ruminal cannulae and the $\mathrm{pH}$ determined immediately. Before each collection, blood samples were drawn into heparinized syringes for analysis of acid-base status and blood gas tensions by blood gas analyser (Radiometer, Copenhagen, Denmark).

The rumen liquor samples were analysed for lactic acid by the method of Barker (1961). Ammonia-N $\left(\mathrm{NH}_{3}-\mathrm{N}\right.$ ) was analysed by the micro diffusion technique (Conway 1957). Total volatile fatty acids were analysed according to the method of Ann is on (1954) and molar proportion of individual fatty acids by gas chromatography (Bernard and Boucque 1968). 
Table 1

Biochemical and microbial changes of rumen liquor under monensin fed subacute lactic acidosis

\begin{tabular}{|c|c|c|c|c|c|c|c|c|c|c|}
\hline \multirow{3}{*}{ Parameters } & \multicolumn{10}{|c|}{ Time (hrs) } \\
\hline & \multirow{2}{*}{0} & \multirow{2}{*}{12} & \multicolumn{2}{|c|}{18} & \multicolumn{2}{|c|}{24} & \multicolumn{2}{|c|}{36} & \multicolumn{2}{|c|}{48} \\
\hline & & & C & $M$ & C & $\mathbf{M}$ & C & $\mathbf{M}$ & C & $\mathbf{M}$ \\
\hline Rumen pH & $\begin{array}{r}6.80 \\
\pm 0.06\end{array}$ & $\begin{array}{r}5.03 \\
\pm 0.03\end{array}$ & 4.87 & $\begin{array}{r}5.49 \\
\pm 0.25\end{array}$ & 4.90 & $\begin{array}{r}5.46 \\
\pm 0.11\end{array}$ & 5.50 & $\begin{array}{r}6.72 \\
\pm 0.17\end{array}$ & 5.99 & $\begin{array}{r}6.61 \\
\pm 0.26\end{array}$ \\
\hline $\begin{array}{l}\text { Lactid acid } \\
(\mathrm{mM} / \mathrm{L})\end{array}$ & $\begin{array}{r}0.32 \\
\pm 0.07\end{array}$ & $\begin{array}{r}13.55 \\
\pm 0.57\end{array}$ & 16.60 & $\begin{array}{r}11.08 \\
\pm 0.38\end{array}$ & 20.70 & $\begin{array}{r}11.28 \\
\pm 1.02\end{array}$ & 11.29 & $\begin{array}{r}2.22 \\
\pm 0.27\end{array}$ & 8.92 & $\begin{array}{r}0.29 \\
\pm 0.06\end{array}$ \\
\hline $\begin{array}{l}\text { Rumen } \\
\mathrm{NH}_{3}-\mathrm{N} \\
(\mathrm{mM} / \mathrm{L})\end{array}$ & $\begin{array}{r}13.72 \\
\pm 0.97\end{array}$ & $\begin{array}{r}9.14 \\
\pm 0.59\end{array}$ & 6.84 & $\begin{array}{r}10.87 \\
\pm 0.79\end{array}$ & 7.49 & $\begin{array}{r}7.74 \\
\pm 0.24\end{array}$ & 5.60 & $\begin{array}{r}9.25 \\
\pm 0.31\end{array}$ & 5.85 & $\begin{array}{r}9.03 \\
\pm 0.44\end{array}$ \\
\hline $\begin{array}{l}\text { TVFA } \\
(\mathrm{mM} / \mathrm{L})\end{array}$ & $\begin{array}{r}102.00 \\
\pm 3.95\end{array}$ & $\begin{array}{r}50.50 \\
\pm 4.69\end{array}$ & 20.00 & $\begin{array}{r}27.30 \\
\pm 1.18\end{array}$ & 16.00 & $\begin{array}{r}30.66 \\
\pm 3.06\end{array}$ & 24.00 & $\begin{array}{r}81.00 \\
\pm 1.34\end{array}$ & 30.00 & $\begin{array}{r}95.56 \\
\pm 1.78\end{array}$ \\
\hline $\begin{array}{l}\text { Molar } \\
\text { proportion } \\
\text { Acetic acid } \\
(\%)\end{array}$ & $\begin{array}{r}50.71 \\
\pm 1.73\end{array}$ & $\begin{array}{r}54.35 \\
\pm 1.91\end{array}$ & 60.62 & $\begin{array}{r}64.47 \\
\pm 5.20\end{array}$ & 62.27 & $\begin{array}{r}64.48 \\
\pm 1.06\end{array}$ & 49.13 & $\begin{array}{r}37.77 \\
\pm 2.70\end{array}$ & 47.51 & $\begin{array}{r}34.91 \\
\pm 2.86\end{array}$ \\
\hline $\begin{array}{l}\text { Propionic } \\
\text { acid (\%) }\end{array}$ & $\begin{array}{r}28.05 \\
\pm 1.74\end{array}$ & $\begin{array}{r}25.64 \\
\pm 1.24\end{array}$ & 27.64 & $\begin{array}{r}24.93 \\
\pm 3.20\end{array}$ & 30.18 & $\begin{array}{r}28.23 \\
\pm 0.88\end{array}$ & 26.05 & $\begin{array}{r}47.54 \\
\pm 3.01\end{array}$ & 37.07 & $\begin{array}{r}46.84 \\
\pm 0.85\end{array}$ \\
\hline $\begin{array}{l}\text { Butyric } \\
\text { acid (\%) }\end{array}$ & $\begin{array}{r}21.20 \\
\pm 1.61\end{array}$ & $\begin{array}{r}20.00 \\
\pm 1.27\end{array}$ & 11.84 & $\begin{array}{r}10.58 \\
\pm 2.53\end{array}$ & 7.55 & $\begin{array}{r}7.27 \\
\pm 1.49 \\
\end{array}$ & 24.82 & $\begin{array}{r}14.68 \\
\pm 0.64\end{array}$ & 15.42 & $\begin{array}{r}18.91 \\
\pm 3.34\end{array}$ \\
\hline
\end{tabular}

C $=$ Control

$M=$ Monensin

\section{Results and Discussion}

There was a decline in the ruminal $\mathrm{pH}$ from $6.80 \pm 0.06$ to $5.03 \pm 0.3$ at $12 \mathrm{~h}$ post-induction. The value further declined to 4.87 at $18 \mathrm{~h}$ in the untreated calf (Table 1).

The rise and fall of ruminal $\mathrm{pH}$ has been correlated with the lactic acid concentration. At $0 \mathrm{~h}$ the concentration of lactic acid was $0.32 \pm 0.07 \mathrm{mM} / \mathrm{L}$ which significantly increased to $13.55 \pm 0.57 \mathrm{mM} / \mathrm{L}$ at $12 \mathrm{~h}$ post-induction in the treated calves. When the first dose of monensin was administered, the level of lactic acid decreased from $13.55 \pm 0.57$ to $11.08 \pm 0.38 \mathrm{mM} / \mathrm{L}$ at $18 \mathrm{~h}$ post-induction. The concentration significantly decreased to $2.22 \pm 0.27 \mathrm{mM} / \mathrm{L}$ after administration of $2 \mathrm{nd}$ dose at $24 \mathrm{~h}$ post-induction. At $48 \mathrm{~h}$ the level of lactic acid was at par $(0.29 \pm 0.06 \mathrm{mM} / \mathrm{L})$ with $0 \mathrm{~h}(0.32 \pm 0.07 \mathrm{mM} / \mathrm{L})$ thus indicating the ability of monensin to control ruminal lactic acid. This ability of monensin to prevent extreme reduction in ruminal $\mathrm{pH}$ during acidosis, that usually accompanies overconsumption of readily fermentable carbohydrates, may be a result of the selective inhibition of major lactic acid producing bacteria, Streptococcus bovis and Lactobacillus spp.

The buffalo calves exhibited a gradual decrease in the TVFA concentration in control as well as monensin-treated calves at $18 \mathrm{~h}$ post-induction. This decreased TVFA concentration was found to improve in the treated calves with the administration of second dose of monensin, where the level reached $95.66 \pm 1.78 \mathrm{mM} / \mathrm{L}$ 
Table 2

Effect of monensin on ruminal protozoan changes in subacute lactic acidosis

\begin{tabular}{|c|c|c|c|c|c|c|c|c|}
\hline \multirow{2}{*}{$\begin{array}{l}\text { Time } \\
\text { inter- } \\
\text { val } \\
\text { (hrs) }\end{array}$} & \multirow{2}{*}{$\begin{array}{l}\text { Total } \\
\text { protozoal } \\
\text { count } \\
\left(10^{5}\right)\end{array}$} & \multicolumn{7}{|c|}{ Differential protozoal count (\%) } \\
\hline & & Isotricha & $\begin{array}{c}\text { Dasytri- } \\
\text { cha }\end{array}$ & $\begin{array}{l}\text { Entodi- } \\
\text { nium }\end{array}$ & $\begin{array}{c}\text { Diplodi- } \\
\text { nium }\end{array}$ & $\begin{array}{l}\text { Epidi- } \\
\text { nium }\end{array}$ & $\begin{array}{l}\text { Ophryo- } \\
\text { scolex }\end{array}$ & $\begin{array}{l}\text { Uniden- } \\
\text { tified }\end{array}$ \\
\hline 0 & $\begin{array}{r}2.92 \\
+016\end{array}$ & $\begin{array}{r}27.75 \\
+143\end{array}$ & $\begin{array}{r}7.25 \\
+0.73\end{array}$ & $\begin{array}{r}21.00 \\
+111\end{array}$ & $\begin{array}{r}31.75 \\
+0.73\end{array}$ & $\begin{array}{r}5.50 \\
+055\end{array}$ & $\begin{array}{r}1.75 \\
+0.41\end{array}$ & $\begin{array}{r}5.75 \\
\end{array}$ \\
\hline 6 & $\begin{array}{c}0.38^{*} \\
\pm 0.04\end{array}$ & $\begin{array}{l}8.30^{*} \\
\pm 1.06\end{array}$ & - & $\begin{array}{c}46.20^{*} \\
\pm 5.28\end{array}$ & $\begin{array}{l}43.00^{*} \\
\pm 4.43\end{array}$ & - & - & $\begin{array}{c}2.50^{*} \\
+0.09\end{array}$ \\
\hline 12 & - & - & - & - & - & - & - & - \\
\hline 18 & - & - & - & - & - & - & - & - \\
\hline 24 & - & - & - & - & - & - & - & - \\
\hline 36 & - & - & - & - & - & - & - & - \\
\hline 48 & - & - & - & - & - & - & - & - \\
\hline
\end{tabular}

* Significant at $\mathrm{P}<0.05$

$(-)$ Activity absent

at $48 \mathrm{~h}$ post-induction, whereas there was a constant decline in TVFA concentration in the untreated calf.

The administration of monensin at $12 \mathrm{~h}$ did not increase the molar proportion of individual volatile fatty acids. However, administration of second dose resulted in a decrease in the ruminal acetate and butyrate production at 36 and $48 \mathrm{~h}$ (Table 1) post-induction. Ruminal concentrations of propionate were not affected by monensin treatment during the initial $24 \mathrm{~h}$, however, after this the propionate level increased in response to monensin treatment. The increase in molar proportion was largely the result of a decreased concentration of acetate and butyrate; although Shell et al. (1983) attributed similar changes in the molar proportion to a direct increase in the propionate production. Similar observations have also been recorded in cattle by Burrin and Britton (1986).

It has been demonstrated by Chen and Wolin (1979) that monensin alters the proportions of ruminal VFA production by selective inhibition against gram-positive species that produce acetate, butyrate, hydrogen, formate and allowing gram-negative propionate producing species to proliferate.

Regardless of monensin treatment, calves did not exhibit any increase in ammonia nitrogen $\left(\mathrm{NH}_{3}-\mathrm{N}\right)$ concentration at $24 \mathrm{~h}$ post-induction; however, after 36 and $48 \mathrm{~h}$. $\mathrm{NH}_{3}-\mathrm{N}$ concentration was less in the non-treated calf in comparison to monensin administered calves.

The average total rumen protozoan count recorded at $0 \mathrm{~h}$ was $2.92 \pm 0.14 \times$ $\times 10^{5} / \mathrm{ml}$ of rumen liquor and differential protozoal count revealed predominance of Diplodinium with counts of $31.75 \pm 0.73 \%$ followed by Isotricha $27.75 \pm 1.43$, Entodinium $21.00 \pm 1.11$, Dasytricha $7.25 \pm 0.73$, unidentified protozoan $5.75 \pm$ \pm 0.40 , Epidinium $5.50 \pm 0.55$ and Ophryoscolex spp. (Table 2) $1.75 \pm 0.41$ per cent. However, following induction of subacute lactic acidosis, complete disappearance of the protozoa was observed by $12 \mathrm{~h}$ which persisted subsequently throughout the period of observation of $48 \mathrm{~h}$ post-induction both in monensin-treated and untreated buffalo calves. The disappearance of the protozoa in the present observation could be related to the fact that lysis of the rumen protozoa has been reported when the rumen $\mathrm{pH}$ falls below 5.5 (Hungate 1966) and may also be 


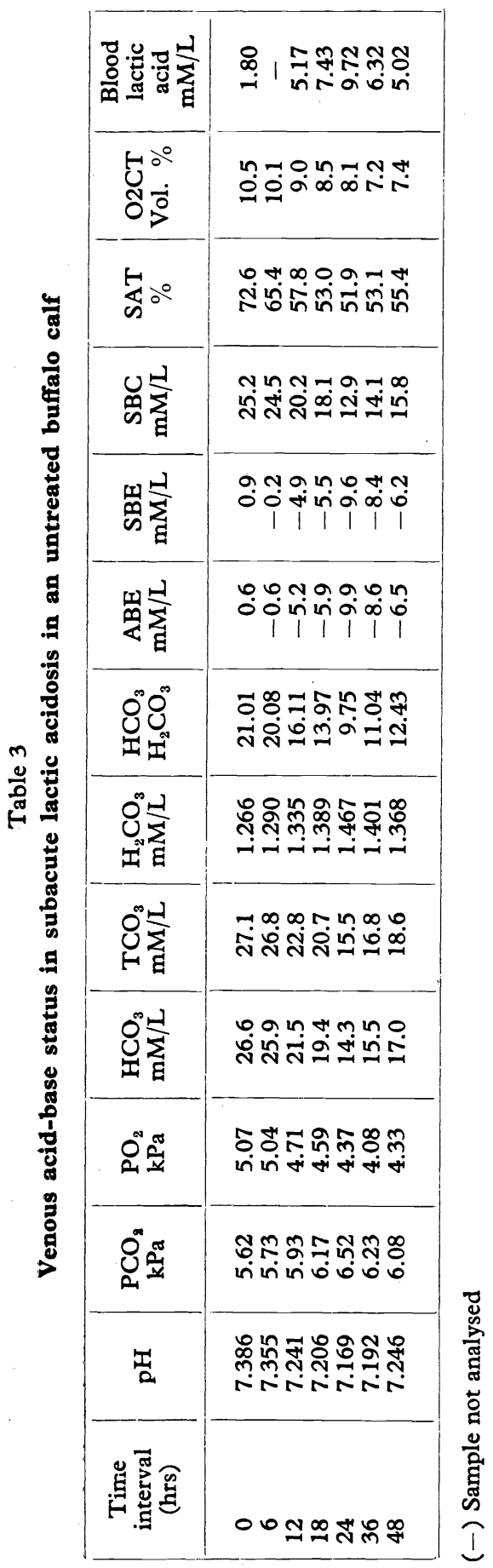

due to increased osmotic pressure of the ruminal environment. $\mathrm{Rich}$ ards on et al. (1978) have shown that monensin feeding decreases protozoa population in the rumen. Dennis et al. (1981) also demonstrated that monensin reduces the protozoa population in both in vitro and in vivo studies. However, no revival of the protozoa could be observed in treated and untreated animals which could be due to short period of observation in the present study as it has been confirmed that in subacute lactic acidotic calves, usually the re-establishment of the protozoa is observed by 108 to $120 \mathrm{~h}$ post-induction.

The predominance of gram-negative bacteria on Gram's staining observed at $0 \mathrm{~h}$ changed to gram-positive flora by 12 th hour of post-induction which persisted upto 18 th h. However, by $24 \mathrm{~h}$ in the treated group almost equal proportion of gram-positive to gram-negative bacteria was observed which changed to $0 \mathrm{~h}$ pattern by $36 \mathrm{~h}$. But in the untreated calf, the predominance of gram-positive flora persisted throughout the period of observation. Aerobic bacterial cultural isolation studies of healthy rumen liquor revealed mainly coliform bacteria with few colonies of Streptococcus bovis. Subsequent culturing at $12 \mathrm{~h}$ after induction of subacute lactic acidosis revealed predominance of Streptococcus bovis and Lactobacilli spp. with isolation of few colonies of coliform bacteria. Even at $18 \mathrm{~h}$, there was no marked qualitative change in the pattern of the bacterial flora except decrease in Lactobacilli spp. But cultural isolation studies at $24 \mathrm{~h}$ revealed marked decrease in the number of Streptococcus bovis colonies with proportionate increase in the number of coliform organisms with complete absence of Lactobacilli spp. Subsequent analysis of rumen liquor samplings at 36 and $48 \mathrm{~h}$ also revealed absence of Lactobacilli spp. with isolation of few colonies of St.bovis and predominance of coliform organisms. This is similar to the observations of Dennis et al. (1981) and Burrin and Britton (1986) which 
confirmed the inhibitory effect of monensin on amylolytic bacteria. In the untreated calf, Lactobacilli spp. could be isolated up to $36 \mathrm{~h}$ post-induction with significant decrease in the number of coliform colonies and proportionate increase in Streptococcus bovis persisting even up to $48 \mathrm{~h}$ of observation indicating active proliferation of gram-positive amylolytic bacteria which helps in maintaining ruminal $\mathrm{pH}$ to a significant low level with excessive accumulation of lactic acid in rumen liquor.

At $0 \mathrm{~h}$ the concentration of lactic acid was $1.81 \mathrm{mM} / \mathrm{L}$ and the level increased to $9.78 \mathrm{mM} / \mathrm{L}$ at $24 \mathrm{~h}$ post-induction in the untreated calf. Subsequently, the concentration decreased at 36 and $48 \mathrm{~h}$ and the values were 6.32 and $5.02 \mathrm{mM} / \mathrm{L}$, respectively. However, in the treated group, though initially the blood lactate concentration increased significantly from $0 \mathrm{~h}$ mean value of 2.18 to $4.94 \mathrm{mM} / \mathrm{L}$ by 12 th $\mathrm{h}$ post-induction, this increase persisted even after administration of first dose of monensin. However, with the oral administration of second dose of monensin, the blood lactate concentration declined sharply approaching normal values by $48 \mathrm{~h}$ of observation. The decline in blood lactate concentration in the treated group correlated with the significant reduction in the ruminal lactic acid concentration probably resulting due to inhibitory effect of monensin on lactate production in the rumen. The decreasing blood lactate concentrations might also be as a result of its metabolism by the ruminal epithelium during absorption or utilization by hepatic gluconeogenesis or incorporation into fatty acids in adipose tissue. Comparative analysis of the ruminal and blood lactic concentrations revealed that lactacidemia between 18 to $24 \mathrm{~h}$ following induction of lactic acidosis was not only of gastrointestinal origin but also from tissues setting in systemic lactic acidosis as a result of failure in aerobic metabolism in view of the decreasing systemic blood pressure leading to decrease in tissue perfusion with subsequent cellular conversion to aerobic glycolytic means for energy production. Studies on blood lactic conversion were contrary to those reported by Nagaraja et al. (1981, 1982). The differential response in buffalo calves in the present study may be a result of differences in experimental conditions.

An acid base analysis of venous blood revealed a significant decrease in $\mathrm{pH}$, $\mathrm{PO}_{2}, \mathrm{HCO}_{3}, \mathrm{HCO}_{3} / \mathrm{H}_{2} \mathrm{CO}_{3}, \mathrm{ABE}, \mathrm{SBE}, \mathrm{SBC}$ and $\mathrm{TCO}_{2}$ by $12 \mathrm{~h}$ post-induction indicating that ruminal acidosis resulted in metabolic acidosis (Table 3). This was accompanied by respiratory acidosis since carbonic acid content and $\mathrm{PCO}_{2}$ increased appreciably which may be due to pulmonary insufficiency and hypoventilation. This is similar to the observations of Vest weber et al. (1979) and Randhawa et al. (1980). There was a significant increase in blood $\mathrm{pH}, \mathrm{HCO}_{3}, \mathrm{ABE}$ and SBE following oral administration of second dose of monensin in the treated group reaching normal values by $36 \mathrm{~h}$ post-induction (Table 4). These alterations indicated that buffalo calves experienced significant systemic acid-base changes up to $24 \mathrm{~h}$ followed by their restoration towards normal values following monensin treatment probably due to marked reduction in the ruminal lactate concentration resulting in its decreased absorption into the systemic circulation. Significant difference in the $\mathrm{HCO}_{3}, \mathrm{SBE}, \mathrm{TCO}_{2}, \mathrm{ABE}$ and $\mathrm{SBE}$ in response to monensin treatment by $36 \mathrm{~h}$ post-induction observed in the present study is contrary to the findings of Burrin and Britton (1986). They reported no differences in blood $\mathrm{HCO}_{3}$ in response to monensin treatment. These differences could be ascribed to the differences in experimental design and species variation. However, in the untreated calf the peak ruminal acidity was correlating with the systemic acidity indicating inability of the body systems to utilize the compensatory me- 


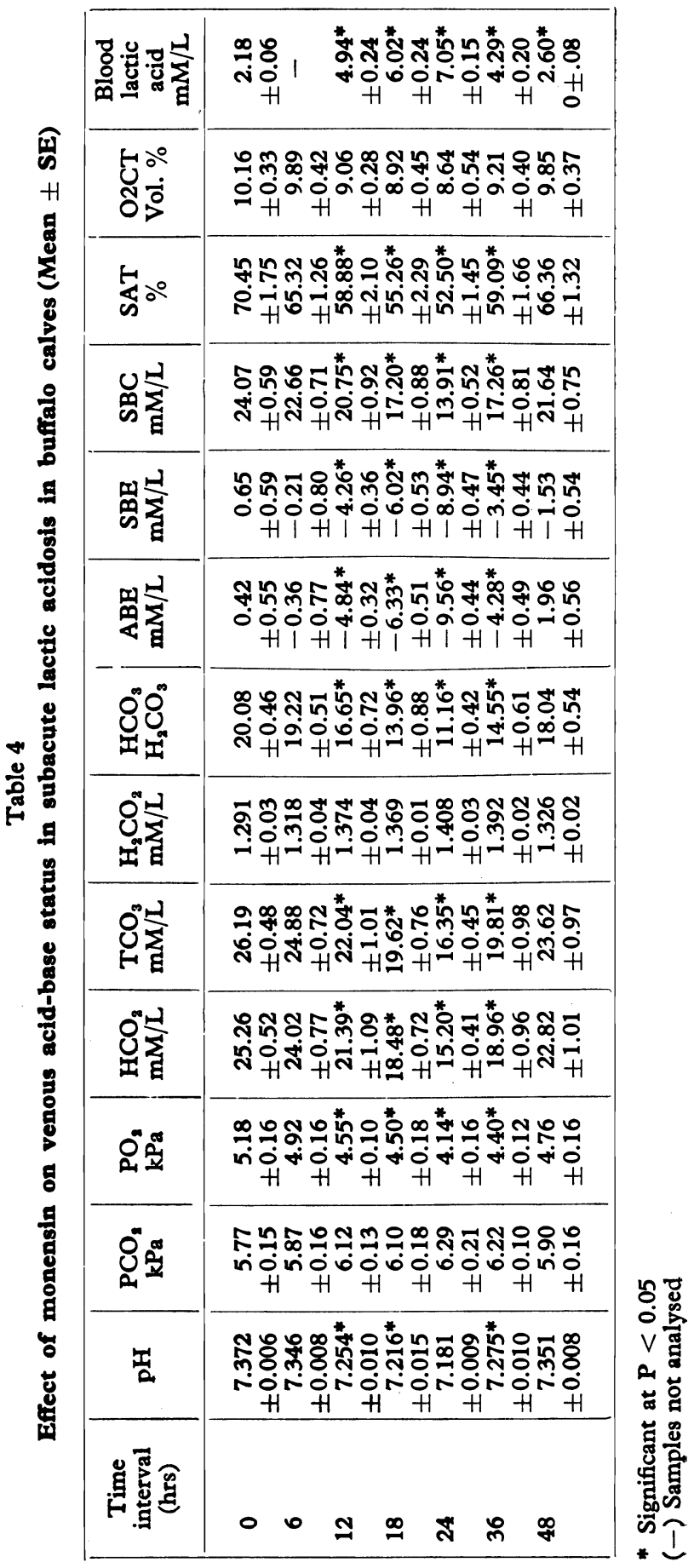


chanisms to neutralize the systemic acidosis even by $48 \mathrm{~h}$ after induction of lactic acidosis (Table 1).

Clinically, all typical symptoms of subacute lactic acidosis like anorexia, ruminal stasis, marked dullness and depression with drooping head, reluctance to move, ataxic gait and passing diarrhoeic faeces with moderate abdominal distension were seen in buffalo calves. However, following treatment by $36 \mathrm{~h}$ all the calves in the treated group restored their normal appetite with restoration of ruminal movements and passing normal faeces, but in the untreated group, the calf was still anorectic, passing diarrhoeic faeces with ruminal stasis. It would be, thus, inferred from the results of the present trial that oral administration of monensin was effective in combating ruminal acidosis and subsequently developing systemic acidosis in buffalo calves as confirmed by detailed clinico-biochemical and microbiological analysis of the rumen liquor and acid-base analysis of the blood.

\section{Účinek monensinu na zmírnění subakutní laktacidózy u telat buvolů}

Byl hodnocen účinek podávání monensinu na bachorový metabolismus, acidobazický stav a tlak krevních plynů u subakutní laktacidózy vyvolané u telat buvolů podáním melasy. Subakutní laktacidóza byla vyvolána jednorázovým orálním podáním melasy v množství $10 \mathrm{~g} \cdot \mathrm{kg}^{-1}$ tělesné hmotnosti. Bylo zjištěno, že monensin je účinný při úpravě $\mathrm{pH}$ bachoru a že významně snižuje obsah kyseliny mléčné $\mathrm{v}$ bachorové štávě. Koncentrace celkových těkavých mastných kyselin (TMK) a $\mathrm{C}_{2} / \mathrm{C}_{3}$ nebyla ovlivněna první dávkou monensinu 12 hod. po experimentálnim vyvolání acidózy. Avšak podání druhé dávky za 24 hod. zpưsobilo zřetelné zvýšení TMK související s poklesem tvorby acetátu a butyrátu $\mathrm{v}$ bachoru a proporcionálním zvýšením koncentrace propionátu $\mathrm{v}$ bachoru. Také obsah kyseliny mléčné v krvi významně poklesl u skupiny s aplikací monensinu, což ukázalo jeho účinnost $\mathrm{v}$ zabránění vývoje systémové acidózy. Při acidobazické analýze venózní krve se projevilo zlepšení hodnot aktuálního bikarbonátu, standardního bikarbonátu, přebytku bázı a poměru bikarbonátu ke kyselině uhličité.

\section{Воздействие монэнзина на смягчение подострого пактацидоза телят бүйволов}

Проводиле оценку воздействия дачи монэнзина на метаболизм рубца, кислотно-основное состояние и давление крови газов у подострого лактацидоза, вызванного у телят бүйволов дачей мелассы. Подострый лактацидоз был вызван однократной оральной дачей мелассы в количестве 10 г.кг-1 массы тела. Было установлено, что монэнзин действенен при приведении в норму $\mathrm{pH}$ рубца и что он существенно понижает содержание молочной кислоты в соках рубца. Концентрация общих летүчих жирных кислот (ЛЖК) и $\mathrm{C}_{2} / \mathrm{C}_{3}$ не оказалась под влиянием первой дозы монэнзина в течение 12 часов после экспериментально. вызванного ацидоза. Однако дача второй дозы через 24 часа вызвала явное повышение ЛЖК, связанное с понижением образования ацетата и бутирата в рубце и пропорциональным повышением в нем концентрации пропионата. Содержание молочной кислоты в крови также существенно понизилось у группы, принимаемой монэнзин, что свидетельствует о его воздействии, препятствующем развитию системного 
ацидоза. В ходе кислотно-основного анализа венозной крови было выявлено улучшение величин актуального бикарбоната, стандартного бикарбоната, излишка основы и соотношения бикарбоната и угольной

\section{Acknowledgement}

The authors thank the Indian Council of Agricultural Research, New Delhi for financing the project.

\section{References}

ANNISON, E. F.: Some observations on volatile fatty accids in sheep rumen. Biochem. J., 57, 1954: $400-405$.

BARKER, S. B.: Standard Methods of Clinical Chemistry. Vol. III, Academic Press, New York, 1961.

BERNARD, G. C. - BOUCQUE, C. V.: Rapid method for the gaschromatographic determination of volatile fatty acids in rumen fluid. J. Agri. Food Chem., 16, 1968: 105.

BURRIN, D. G.-BRITTON, R. A.: Response to monensin in cattle during subacute acidosis J. Anim. Sci. 63, 1986: 888-893.

CONWAY, E. J.: Microdiffusion analysis and volumetric errors. Crossby Lockwood and Sons, London, 1957.

CHEN, M. - WOLIN, M. J.: Effect of monensin and lasalocid sodium on the growth of methanogenic and rumen saccharolytic bacteria. Appl. Environ. Microbiol. 38, 1979: 72.

DENNIS, S. M. -NAGARAJA. T. G. - BARTLEY, E. E.: Effect of lasalocid or monensin on lactate producing or using rumen bacteria. J. Anim. Sci., 52, 1981: 418-426.

HUNGATE, R. E.: The Rumen and its Microbes, Academic Press, New York, 1966.

NAGARAJA, T. G. - AVERY, T. B.-BARTLEY, E. E.-GALITZER, S. J.-DAYTON, A. D.: Prevention of lactic acidosis in cattle given lasalocid or monensin. J. Anim. Sci. 53, 1981: 206-216.

NAGARAJA, T. G.-AVERY, T. B.-BARTLEY, E. E.-ROOF, S. K.-DAYTON, A. D.: Effect of lasalocid, monensin or thiopeptin on lactic acidosis in cattle. J. Anim. Sci. 54, 1982: $649-658$.

RANDHAWA, S. S.-SINGH, J.-MISRA, S. K.: An experimental study of acid-base studies of buffalo calves in rumen acidosis. Zbl. Vet. Med. A. 27, 1980: 255-258.

SHELL, L. A. - HALL, W. H. - THERURER, B. - SWINGLE, R. S.: Effect of monensin on total volatile fatty acid production by steers fed a high grain diet. J. Anim. Sci., 57, 1983: 178.

VESTWEBER, J. G. E.-LEIPOLD, M. N. -SMITH, J. E.: Ovine tuminal acidosis: Clinical Studies. Am J. Vet. Res. 35, 1974, 1587. 